\title{
Stunting among Children Attending a Pediatrics Outpatient Clinic in Cairo, Egypt
}

\section{Amani Osman Mahmoud ${ }^{1}$ Khaled Mahmoud Zayed ${ }^{2}$ Naglaa Ahmed Shawky Arafa $^{3}$ Abdelghafar Ibrahim Mahmoud Eid ${ }^{4}$}

${ }^{1}$ Paediatrics Department, Faculty of Medicine - Ain Shams University. ${ }^{2}$ Paediatrics Department, Faculty of Medicine - Al Azhar University. ${ }^{3}$ Community, Environmental and Occupational Medicine, Faculty of Medicine - Ain Shams University. ${ }^{4}$ Ministry of Health and Population, Egypt

Received: March 2016 Accepted :June 2016

\begin{abstract}
Background: Stunting is a considerable problem in developing countries, contributing to increasing under-five mortality, while children of stunted mothers have a higher risk of stunting. Objective: to determine the prevalence and risk factors of stunting among children aged 1-12 years attending the outpatient Paediatrics clinic of Al-Azhar University Hospital (Al-Hussein), Cairo. Participants and methods: the anthropometric measurements of 800 children aged 1-12 years with no history of chronic diseases attending the paediatrics outpatient clinic of Al-Hussein Hospital were recruited and a short questionnaire was administered. Results: the prevalence of stunting was $15.8 \%$ with no sex variation. Stunting was found to be associated with parental consanguinity, mother's employment status, and a family history of short stature. Conclusion: there is considerable stunting prevalence rate among this study group. The public should be educated about the importance of avoiding consanguineous marriage. It is important to reduce stunting, especially among girls, to prevent their children from in turn being stunted.
\end{abstract}

Keywords: stunting, short stature, children, consanguinity, Cairo

Corresponding author: Naglaa Ahmed Shawky Arafa Email: naglaaarafa@yahoo.com

\section{Introduction}

Stunting is identified as having a heightfor-age less than minus two standard deviations (-2 SD) from the median of the reference population, against growth standards generated by WHO from data collected in a Multicentre Growth Reference Study. ${ }^{1}$ The Egypt Demographic and Health Survey of 2008 (EDHS 2008) revealed that the prevalence of stunting among children under 5 was $28.9 \%^{2}$, while that of the EDHS 2014 was found to be $21 \%$. $^{3}$

Stunting constitutes a major public health problem in low and middle-income countries. The Maternal and Child Undernutrition Study Group, using cohort data from five low- and middleincome countries found that low birth weight and childhood stunting were associated with short adult stature, reduced lean body mass, less schooling, diminished intellectual functioning, and reduced earnings. ${ }^{4}$ Moreover, a vicious cycle is established, as infants of women who had been stunted as children were found to have a lower birthweight. The children of stunted women also have a higher mortality risk than children of mothers with normal height. ${ }^{5}$ Stunting contributes to $14.5 \%$ of annual deaths among under-five children, and $12.6 \%$ of disability adjusted life-years (DALYs). ${ }^{6}$ 
Little information is available on the prevalence of stunting among children in age groups older than five, or possible risk factors of stunting among the Egyptian population.

Objective: The objective of this study is to determine the prevalence and risk factors of stunting among children aged 1-12 years attending the outpatient Paediatrics clinic of Al-Hussein University Hospital, Cairo.

\section{Methods}

A cross-sectional study was performed among children attending the Outpatient Paediatrics Clinic of El Hussien University Hospital, during the period from March 2011 to July 2011. This is a tertiary hospital serving a large population, with patients attending not only from the surrounding urban areas, but also from rural areas.

A total of 800 children aged 1-12 years were included in the study. Exclusion criteria were: clinical evidence of growth hormone, thyroid or sex steroid deficiency; clinical evidence of an underlying chronic disease or skeletal dysplasia; history of chronic disease.

A full history was taken from parents, including personal history, birth order, parental occupation and education, school status of child, housing, (number of bedrooms), place of residence, past history and family history.

A complete physical examination was performed to exclude occult systemic illness (e.g. congenital heart disease, malabsorption, chronic liver diseases, chronic asthma, chronic renal failure, or chronic anemia), hormonal deficiencies, *e.g. growth hormone deficiency, hypothyroidism, Cushing syndrome or hypogonadism). Further laboratory investigations were not performed as this was outside the scope of the study.

Height was measured using a Harpenden Stadiometer. The patient, dressed only in underclothes, stood with heels together and head in the Frankfurt plane (that is, with the lower border of the orbit in the same horizontal plane as the external auditory meatus) The top of the Stadiometer, being counterbalanced, rested lightly on the patient's head. The patient then stretched upwards fully, aided by relaxing the shoulders and by the anthropometrist applying gentle upward pressure on the mastoid processes, and encouraging him verbally. The recorder saw that the heels did not come off the ground, holding them down if necessary. The height was read from a counter attached to the Stadiometer. Heights of each child were plotted on WHO reference charts to identify stunted children.

Statistical analysis: Crowding index was calculated according to the following equation (number of persons in the household divided by the number of rooms used for sleeping). The crowding index was then divided into categories. Frequencies and percentages of qualitative variables were calculated. Qualitative data were analysed using the chi-squared test. Logistic regression analysis was performed to estimate the contribution of each variable to stunting. All data were analysed using Stata version 11 (StataCorp. 2009. Stata Statistical Software: Release 11. College Station, TX).

Ethical consent: Permission was obtained from the ethical committees of the Faculty of Medicine, Ain Shams University, and from Faculty of Medicine, Azhar University.

\section{Results}

The characteristics of the study sample are shown in table 1 . The sample was equally divided between males (49.38\%) and females $(50.63 \%)$. Their mean age was $5.35 \pm 3.08$ years. Almost two-thirds were below school age, while $37.35 \%$ were attending school. Only $1.75 \%$ was not attending school. Almost half 
$(42.75 \%)$ were of first birth order, followed by second and third birth orders. One-quarter of children were of consanguineous parents. The characteristics of the subjects' families are shown in table 2. The father's educational status was illiterate for $18.38 \%$ of children, and able to read and write for $32.75 \%$. A quarter of mothers were illiterate, and a further $40 \%$ could only read and write. $92.5 \%$ of mothers were unemployed. The large majority of children were from rural areas.

The prevalence of stunting among children aged 1-12 years in this study was $15.8 \%$. As shown in the figure, the prevalence varied greatly by age, showing peaks at age 1 year $(29.3 \%), 4$ years $(26.1 \%), 6$ years $(18.5 \%), 9$ years $(17.0 \%)$ and 12 years $(36.4 \%)$. Stunting was not associated with sex or birth order (table 3). However, there was a strong statistical association between stunting and parental consanguinity, with about $22 \%$ of children of consanguineous parents being stunted, compared to only $13 \%$ of children of non-consanguineous parents. Stunting was found to be associated with paternal education, with the lowest level of stunting found among children of fathers with university education $(5.7 \%)$. Stunting was not associated with maternal education or paternal employment; however, there was a strong association between stunting and maternal employment, with almost one-third of children of mothers who work having stunted children, compared to only $14 \%$ of children of non-working mothers. There was no association between stunting and place of residence (urban or rural areas). Family history of short stature was strongly associated with stunting, with about half of children of parents of short stature being stunted, compared to only $13 \%$ of children with no family history of short stature. There was no association between stunting family income and crowding index. On multivariable logistic regression analysis (table 4), only parental consanguinity, maternal employment, and family history of short stature were found to be associated with stunting.

\section{Discussion}

There is a rising concern about the prevalence of stunting among Egyptian children. The EDHS 2008 reported that overall, the prevalence of stunting among Egyptian children under five was 29 percent of children. ${ }^{2}$ More recently, the EDHS 2014 showed that stunting levels have appeared to decrease over the previous period, to $21.4 \%$, which is however still considerable. ${ }^{3}$ The prevalence of stunting among the present study group was found to be $15.8 \%$, which is somewhat lower than that reported for urban governorates in the EDHS 2014 (19\%). ${ }^{3}$

The present study showed that stunting levels varied considerably by age. The EDHS 2014 showed a similar phenomenon, with three different peaks at ages 24, 38 and 58 months. Moreover, the present study showed no relationship between sex and stunting, which is also similar to the results of the EDHS 2014 (3), and confirmed also by Zotarreli et al., 2007 who reported that the prevalence of stunting in Egyptian male children was $19.85 \%$, compared to $17.42 \%$ among female children. ${ }^{7}$

In the present study, there was no relationship between birth order stunting. Zotarreli et al, 2007 had reported that children of the first birth order had higher risk of stunting compared to children of higher birth orders. ${ }^{7}$ However, an analysis of data from Demographic and Health Surveys performed from 2006 to 2012 in several countries showed the opposite, with children of first and second birth orders having the lowest risk of stunting. ${ }^{8}$ It is possible that the effect of birth order differs by country. 
Parental consanguinity was a strong risk factor for stunting. The 2014 EDHS showed that consanguinity is more common among those residing in rural areas, of lower educational status, and of lower wealth quintile, which are all potential risk factors for stunting. ${ }^{3}$ However, the association between consanguinity and stunting in this study remained even after logistic regression which controlled for these potential confounders. This finding is in agreement with Zotarreli et al., 2007 who concluded that the risk of stunting was higher among children born to consanguineous parents, whether the degree of consanguinity was first or second degree, or other blood relation. ${ }^{7}$

The EDHS 2014 revealed a modest difference in prevalence of stunting among children of mothers who had completed secondary education or higher, namely $24.5 \%$, compared to $19.4 \%$ among children of mothers with no education. ${ }^{3}$ The present study showed a similar trend in the association between educational level and stunting in univariate analysis. A cross-sectional study performed on children aged 6-24 months attending primary health care centers in El-Minia city, had also reported similar findings, with higher odds ratio for stunting $(\mathrm{OR}=3.0,95 \%$ CI: 2.14 - 4.26) among children of mothers with less than secondary education. ${ }^{9}$ Similarly, a study of children attending the outpatient malnutrition clinic of Cairo University revealed that children of illiterate mothers had a higher risk of malnutrition. ${ }^{10}$ However, this association was not sustained in multivariate analysis.

The children of mothers who worked had higher prevalence of stunting as compared to mothers who did not; these findings were not apparent in the EDHS 2008, which showed no difference in stunting rates according to the work status of mothers. ${ }^{2}$ The EDHS 2014 did not present the stunting prevalence according to the work status of the mother. ${ }^{3}$ Seedhom et al reported in more detail that the mean height for age $\mathrm{z}$ score differed according to the type of maternal occupation. In their study, they reported that compared to housewives, children of women of professional occupations had the highest mean $\mathrm{z}$ scores, while children of mothers who were engaged in manual work had the lowest mean $\mathrm{z}$-scores. ${ }^{9}$ Considering that women who attend at the El Hussien University Hospital are of lower socioeconomic classes, it is probable that women who work in this sample work in manual occupations, which would account for why children of working mothers in our study have a higher prevalence of stunting.

Family history of short stature was also strongly associated with stunting in the present study. Seedhom et al, had also reported that a maternal height of $\leq 160$ $\mathrm{cm}$ was strongly associated with stunting ${ }^{9}$, while Zotarelli et al had also confirmed that compared to a maternal height of $<150 \mathrm{~cm}$, children of taller mothers had lower odds of stunting. ${ }^{7}$ A study using data from 109 Demographic and Health Surveys from around the world had also demonstrated that the risk for stunting among children of tall mothers was considerably less than that of children of the shortest mothers ${ }^{5}$, while a separate study by Victora et al, had also demonstrated that children of stunted mothers had increased risk of stunting. ${ }^{4}$

On univariate analysis, the present study also showed that higher crowding index is associated with stunting. However, this association was not sustained in logistic regression. AbdElAziz and Hegazy, 2012 who had investigated undernutrition among infants in outpatient clinics in Egypt, had demonstrated that larger family size was associated with stunting. ${ }^{10}$ However, an analysis of a 
large data set of Indian children revealed no association between number of household members and stunting. ${ }^{11}$

The present study showed that there is no association between family income and stunting, which is similar to the findings of the EDHS 2014, which showed similar rates of stunting across all wealth quintiles ${ }^{3}$. On the other hand, a multilevel analysis on the EDHS 2008 data, reported that the risk of stunting increased by decreasing wealth quintile. ${ }^{12}$ Similarly, Seedhom et al, demonstrated a higher risk of stunting among children of lower socio-economic status. ${ }^{9}$

\section{Conclusion}

There is considerable stunting rate among the study population. It is important to educate the general public on the importance of avoiding consanguineous marriage. Considerable effort is also needed to improve the nutritional status of the population, and especially of girls, to prevent the next generation from suffering from stunting.

Conflict of interest: the authors declare that they have no conflicts of interest. No funding was received to carry out this study.

\section{References}

1. World Health Organization (WHO). 2006. WHO Child Growth Standards: Length/height-for-age, Weight-for-age, Weight-for-length, Weight-for-height and Body Mass Index-for-age: Methods and Development. Geneva: WHO. Available online at http://www.who.int/ growthref/who2007_height_for_age/en/.

Accessed on 9/7/2016.

2. El-Zanaty, Fatma and Ann Way. 2009. Egypt Demographic and Health Survey 2008. Cairo, Egypt: Ministry of Health, El-Zanaty and Associates, and Macro International.

3. Ministry of Health and Population [Egypt], El-Zanaty and Associates [Egypt], and ICF International. 2015.
Egypt Demographic and Health Survey 2014. Cairo, Egypt and Rockville, Maryland, USA: Ministry of Health and Population and ICF International.

4. Victora CG, Adair L, Fall C, Hallal PC, Martorell R, Richter L et al. (2008). Maternal and child undernutrition: consequences for adult health and human capital. Lancet. 371, 340-357.

5. Özaltin E, Hill K, Subramanian SV. 2010. Association of maternal stature with off spring mortality, underweight, and stunting in low- to middle-income countries. JAMA.303:1507-16.

6. Black RE, Allen LH, Bhutta ZA, Caulfield LE, De Onis M, Ezzati M, Mathers C, Rivera J, Maternal and Child Undernutrition Study Group. Maternal and child undernutrition: global and regional exposures and health consequences. Lancet. 2008;371:243-60. 7. Zottarelli LK, Sunil TS, Rajaram S (2007). Influence of parental and socioeconomic factors on stunting in children under 5 years in Egypt. Eastern Mediterranean Health Journal.13:133042

8. Rutstein S and Winter R. (2014). The Effects of Fertility Behavior on Child Survival and Child Nutritional Status: Evidence from the Demographic and Health Surveys, 2006 to 2012. 2014. DHS Analytical Studies No. 37. Rockville, Maryland, USA: ICF International.

9. Seedhom AE, Mohamed ES, Mahfouz EM. (2014). Determinants of stunting among preschool children, Minia, Egypt. International Public Health Forum. 1: 6-9. 10. AbdElAziz SB and Hegazy R. (2012). Socioeconomic risk factors of malnutrition among Egyptian children between 6 months and 2 years of age, Cairo, Egypt. J of the Egyptian Public Health Association. 87:124-130

11. Fenske N, Burns J, Hothorn $\mathrm{T}$, Rehfuess EA (2013) Understanding Child Stunting in India: A Comprehensive Analysis of Socio-

No. 3 July


Economic, Nutritional and among under-five children in Egypt:

Environmental Determinants Using contextual determinants of an individual Additive Quantile Regression. PLoS consequence. International Journal of ONE.8:e78692.

12. Mazumdar S (2012). Assessing Population Research.2012. vulnerability to chronic undernutrition 
Table 1: Characteristics of the studied subjects

\begin{tabular}{|c|c|}
\hline & Number (\%) \\
\hline \multicolumn{2}{|r|}{ (2) } \\
\hline - Female & $395(50.63)$ \\
\hline - Male & 405 (49.38) \\
\hline \multicolumn{2}{|l|}{ Birth order } \\
\hline - First & $342(42.75)$ \\
\hline - Second & $201(25.1)$ \\
\hline - Third & $160(20.00)$ \\
\hline - Fourth and above & $97(12.1)$ \\
\hline \multicolumn{2}{|l|}{ Place of residence } \\
\hline - Rural & $643(80.38)$ \\
\hline - Urban & $157(19.63)$ \\
\hline \multicolumn{2}{|l|}{ School status } \\
\hline - Below age & $488(61.00)$ \\
\hline - Attending school & $298(37.25)$ \\
\hline - Out of school & $14(1.75)$ \\
\hline \multicolumn{2}{|l|}{ Parental consanguinity } \\
\hline $\begin{array}{l}\text { - } \mathrm{No} \\
\text { - Yes }\end{array}$ & $\begin{array}{l}600(75.0) \\
200(25.0)\end{array}$ \\
\hline - Yes & \\
\hline
\end{tabular}

Table 2: Characteristics of subjects' families

\begin{tabular}{|c|c|}
\hline & No. (\%) \\
\hline $\begin{array}{c}\text { Father's education } \\
\text { - Illiterate } \\
\text { - Read and write } \\
\text { - Preparatory } \\
\text { - Secondary } \\
\text { University }\end{array}$ & $\begin{array}{l}147(18.38) \\
262(32.75) \\
147(18.38) \\
138(17.25) \\
106(13.25) \\
\end{array}$ \\
\hline $\begin{array}{c}\text { Father's employment } \\
\bullet \quad \text { Unemployed } \\
\bullet \quad \text { Employed }\end{array}$ & $\begin{array}{l}222(27.75) \\
578(72.25) \\
\end{array}$ \\
\hline $\begin{array}{l}\text { Mother's education } \\
\text { - Illiterate } \\
\text { - Read and write } \\
\text { - Preparatory } \\
\text { - Secondary } \\
\text { - University }\end{array}$ & $\begin{array}{r}204(25.50) \\
315(39.38) \\
94(11.75) \\
139(17.38) \\
48(6.00) \\
\end{array}$ \\
\hline $\begin{array}{c}\text { Mother's employment } \\
\text { - Employed } \\
\text { - Unemployed }\end{array}$ & $\begin{array}{r}60(7.50) \\
740(92.50)\end{array}$ \\
\hline $\begin{aligned} \text { Family income (EGP) } \\
$\[ \quad \leq 500 \]$ \\
\bullet \quad>500-1000 \\
\bullet \quad>1000-1500 \\
\bullet \quad>1500 \\
\end{aligned}$ & $\begin{array}{r}68(8.5) \\
429(53.6) \\
137(17.1) \\
166(20.8) \\
\end{array}$ \\
\hline $\begin{aligned} \text { Crowding index } \\
\bullet \quad \leq 1 \\
\bullet \quad>1-1.5 \\
\bullet \quad>1.5-2 \\
\bullet \quad>2-2.5 \\
\bullet \quad>2.5\end{aligned}$ & $\begin{array}{r}161(20.10 \\
351(43.9) \\
136(17.0) \\
112(14.0) \\
40(5.0) \\
\end{array}$ \\
\hline
\end{tabular}


Table 3: Univariable analysis of risk factors for stunting

\begin{tabular}{|c|c|c|c|c|}
\hline & Normal height & Stunted & p-value & OR $(95 \%$ CI $)$ \\
\hline $\begin{array}{l}\text { Sex } \\
\text { Female } \\
\text { Male }\end{array}$ & $\begin{array}{l}328(83.0) \\
346(85.4)\end{array}$ & $\begin{array}{l}67(17.0) \\
59(14.6)\end{array}$ & 0.358 & $\begin{array}{l}1 \\
0.83(0.57-1.22)\end{array}$ \\
\hline $\begin{array}{l}\text { Birth order } \\
\text { First } \\
\text { Second } \\
\text { Third } \\
\text { Fourth and above }\end{array}$ & $\begin{array}{r}285(83.3) \\
175(87.1) \\
133(83.1) \\
81(83.5)\end{array}$ & $\begin{array}{l}57(16.7) \\
26(12.9) \\
27(16.9) \\
16(16.5) \\
\end{array}$ & 0.168 & $\begin{array}{l}1 \\
0.75(0.45-1.23) \\
1.02(0.61-1.68) \\
0.99(0.54-1.81) \\
\end{array}$ \\
\hline $\begin{array}{l}\text { Place of residence } \\
\text { Urban } \\
\text { Rural } \\
\end{array}$ & $\begin{array}{l}129(82.2) \\
545(84.8) \\
\end{array}$ & $\begin{array}{l}28(17.8) \\
98(15.2) \\
\end{array}$ & 0.424 & $\begin{array}{l}1 \\
0.824(0.522-1.315)\end{array}$ \\
\hline $\begin{array}{l}\text { Parental } \\
\text { consanguinity } \\
\text { No } \\
\text { Yes }\end{array}$ & $\begin{array}{l}518(86.3) \\
156(78.0)\end{array}$ & $\begin{array}{l}82(13.7) \\
44(22.0)\end{array}$ & 0.000 & $\begin{array}{l}1 \\
1.78(1.19-2.68)\end{array}$ \\
\hline $\begin{array}{l}\text { School status } \\
\text { Below age } \\
\text { Attending school } \\
\text { Out of school } \\
\end{array}$ & $\begin{array}{r}408(83.6) \\
254(85.2) \\
12(85.7) \\
\end{array}$ & $\begin{array}{r}80(16.4) \\
44(14.8) \\
2(14.3) \\
\end{array}$ & 0.822 & $\begin{array}{l}1 \\
0.88(0.59-1.32) \\
0.85(0.19-3.87) \\
\end{array}$ \\
\hline $\begin{array}{l}\text { Father's education } \\
\text { Illiterate } \\
\text { Read and write } \\
\text { Preparatory } \\
\text { Secondary } \\
\text { University }\end{array}$ & $\begin{array}{l}122(83.0) \\
211(80.5) \\
129(87.8) \\
112(81.2) \\
100(94.3) \\
\end{array}$ & $\begin{array}{r}25(17.0) \\
18(12.2) \\
51(19.5) \\
26(18.8) \\
\quad 6(5.7) \\
\end{array}$ & 0.010 & $\begin{array}{l}1 \\
0.42(0.22-0.79) \\
1.93(1.13-3.31) \\
1.13(0.62-2.08) \\
0.30(0.12-0.79)\end{array}$ \\
\hline $\begin{array}{l}\text { Father's employment } \\
\text { Unemployed } \\
\text { Employed }\end{array}$ & $\begin{array}{l}191(86.0) \\
483(83.6)\end{array}$ & $\begin{array}{l}31(14.0) \\
95(16.4)\end{array}$ & 0.390 & $\begin{array}{l}1 \\
1.21(0.78-1.88)\end{array}$ \\
\hline $\begin{array}{l}\text { Mother's education } \\
\text { Illiterate } \\
\text { Read and write } \\
\text { Preparatory } \\
\text { Secondary } \\
\text { University }\end{array}$ & $\begin{array}{r}165(80.9) \\
267(84.8) \\
78(83.0) \\
120(86.3) \\
44(91.7) \\
\end{array}$ & $\begin{array}{r}39(19.1) \\
48(15.2) \\
16(17.0) \\
19(13.7) \\
4(8.3) \\
\end{array}$ & 0.359 & $\begin{array}{l}1 \\
0.76(0.48-1.21) \\
0.87(0.46-1.65) \\
0.67(0.37-1.22) \\
0.38(0.13-1.34) \\
\end{array}$ \\
\hline $\begin{array}{l}\text { Mother's employment } \\
\text { Unemployed } \\
\text { Employed }\end{array}$ & $\begin{array}{r}633(85.5) \\
41(68.3) \\
\end{array}$ & $\begin{array}{r}107(14.5) \\
19(31.7) \\
\end{array}$ & 0.001 & $\begin{array}{l}1 \\
2.74(1.53-4.96) \\
\end{array}$ \\
\hline $\begin{array}{l}\text { Place of residence } \\
\text { Rural } \\
\text { Urban }\end{array}$ & $\begin{array}{l}545(84.8) \\
129(82.2) \\
\end{array}$ & $\begin{array}{l}98(15.2) \\
28(17.8) \\
\end{array}$ & 0.424 & $\begin{array}{l}1 \\
1.21(0.76-1.92)\end{array}$ \\
\hline $\begin{array}{l}\text { Family history of } \\
\text { short stature } \\
\text { No } \\
\text { Yes }\end{array}$ & $\begin{array}{r}652(86.5) \\
22(47.8) \\
\end{array}$ & $\begin{array}{r}102(13.5) \\
24(52.2) \\
\end{array}$ & $<0.001 *$ & $\begin{array}{l}1 \\
6.97(3.77-12.90)\end{array}$ \\
\hline $\begin{array}{l}\text { Family income (EGP) } \\
\leq 500 \\
>500-1000 \\
>1000-1500 \\
>1500\end{array}$ & $\begin{array}{r}56(82.4) \\
352(82.1) \\
124(90.5) \\
142(85.5) \\
\end{array}$ & $\begin{array}{r}12(17.6) \\
77(17.9) \\
13(9.5) \\
24(14.5) \\
\end{array}$ & 0.111 & $\begin{array}{l}1 \\
1.02(0.52-2.0) \\
0.49(0.21-1.14) \\
0.79(0.34-1.65) \\
\end{array}$ \\
\hline $\begin{array}{l}\text { Crowding index } \\
\leq 1 \\
>1-1.5 \\
>1.5-2 \\
>2-2.5 \\
>2.5\end{array}$ & $\begin{array}{r}145(90.1) \\
298(84.9) \\
109(80.1) \\
91(81.3) \\
31(77.5)\end{array}$ & $\begin{array}{r}16(9.9) \\
53(15.1) \\
27(19.9) \\
21(18.8) \\
9(22.5)\end{array}$ & 0.089 & $\begin{array}{l}1 \\
1.62(0.89-2.92) \\
2.25(1.16-4.37) \\
2.09(1.04-4.22) \\
2.3(1.06-6.45)\end{array}$ \\
\hline
\end{tabular}


Table 4: Logistic regression analysis for risk factors of short stature

\begin{tabular}{|l|c|c|c|c|}
\hline & \multirow{2}{*}{ P-value } & \multirow{2}{*}{$\begin{array}{l}\text { Odds } \\
\text { ratio }\end{array}$} & \multicolumn{2}{|l|}{$\mathbf{9 5 . 0 \%}$ C.I for OR } \\
\cline { 4 - 5 } & & & Lower & Upper \\
\hline Parental consanguinity & $<0.001$ & 2.80 & 2.255 & 3.868 \\
\hline Mother's occupation & $<0.001$ & 2.85 & 1.471 & 4.219 \\
\hline Family history of short stature & $<0.001$ & 2.15 & 1.130 & 3.172 \\
\hline
\end{tabular}




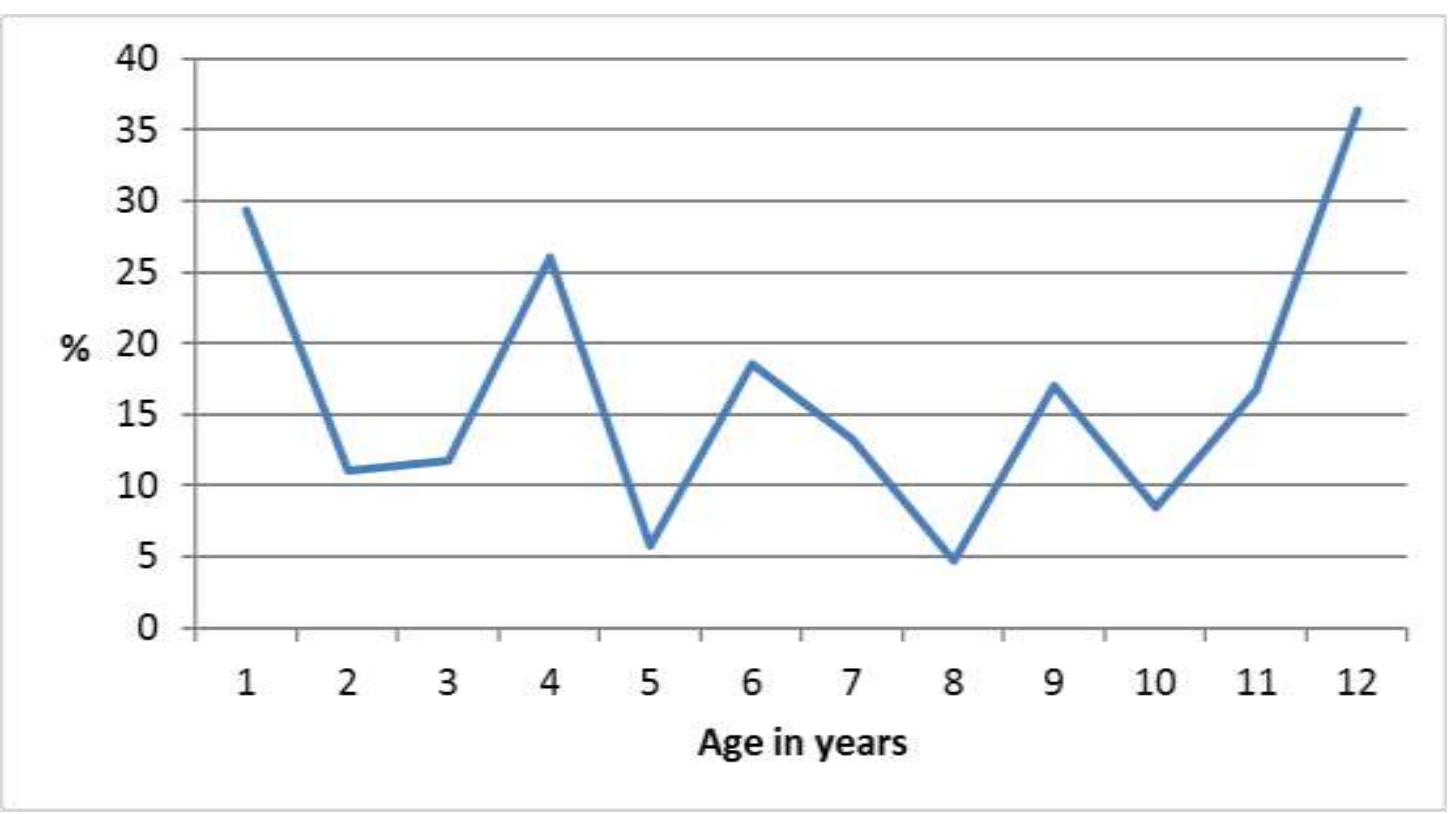

Figure 1: Proportion of Stunted Children by Age 